\title{
Changes in water temperature and oxygen: the effect of triploidy on performance and metabolism in large farmed Atlantic salmon
}

\author{
Florian Sambraus ${ }^{1,2, *}$, Mette Remen ${ }^{1}$, Rolf Erik Olsen ${ }^{1,3}$, Tom Johnny Hansen ${ }^{1}$, \\ Rune Waagbø ${ }^{4}$, Thomas Torgersen ${ }^{1}$, Erik Jan Lock ${ }^{4}$, Albert Imsland ${ }^{2,5}$, \\ Thomas W. K. Fraser ${ }^{1}$, Per Gunnar Fjelldal ${ }^{1}$ \\ ${ }^{1}$ Institute of Marine Research, 5984 Matredal, Norway \\ ${ }^{2}$ Department of Biology, University of Bergen, PO Box 7803, 5006 Bergen, Norway \\ ${ }^{3}$ Institute of Biology, Norwegian University of Science and Technology, 7491 Trondheim, Norway \\ ${ }^{4}$ NIFES - Nasjonalt Institutt for Ernærings- og Sjømatforskning, 5004 Bergen, Norway \\ ${ }^{5}$ Akvaplan-niva Iceland Office, Akralind 4, 201 Kópavogur, Iceland
}

\begin{abstract}
In salmon farming, the use of sterile triploids $(3 \mathrm{~N})$ can mitigate the problem of escapees interbreeding with wild salmon. However, triploid salmon appear less tolerant to high water temperatures and low oxygen levels compared to diploids $(2 \mathrm{~N})$. To investigate how the thermal performance and physiology of large $(2.5 \mathrm{~kg})$ triploid Atlantic salmon Salmo salar L. differs from those of diploids, both ploidies were subjected to water temperatures between 3 and $18^{\circ} \mathrm{C}$. The fish were exposed to reduced oxygen saturations $\left(\mathrm{O}_{2 \text { sat, }}, 70 \%\right)$, termed hypoxia, at 6 and $18^{\circ} \mathrm{C}$. Triploids fed more than diploids between 3 and $9{ }^{\circ} \mathrm{C}$ and at similar levels at $12^{\circ} \mathrm{C}$. At $15^{\circ} \mathrm{C}$, the feed intake significantly dropped in both ploidies, although more in triploids. During hypoxia, feed intake was higher in triploids at $6^{\circ} \mathrm{C}$ and equal to diploids at $18^{\circ} \mathrm{C}$. The overall feed conversion ratio was similar between ploidies. Muscle energy phosphates were generally lower in triploids than diploids, while muscle glucose, blood haemoglobin and haematocrit were lower in triploids than diploids at $\geq 12^{\circ} \mathrm{C}$. Plasma lactate levels tended to be higher in triploids and increased with increasing temperature and at hypoxia in both ploidies. Plasma cortisol increased in both ploidies at high temperatures and was highest in triploids under hypoxic conditions at $18^{\circ} \mathrm{C}$. Triploids had a higher cataract score at the start of the experiment and developed more cataracts throughout the experiment. The present findings show that large triploid Atlantic salmon perform better at colder water temperatures compared to diploids and differ in parts of their physiological expression at increasing and high temperature.
\end{abstract}

KEY WORDS: Ploidy · Sterile $\cdot$ Growth $\cdot$ Feed intake $\cdot$ Thermal optimum $\cdot$ Energy metabolism · Salmo salar

\section{INTRODUCTION}

The use of sterile triploid Atlantic salmon Salmo salar L. mitigates genetic interactions between escaped farmed and wild fish and minimises unwanted sexual maturation before harvest (Taranger et al. 2010). In Norway, the number of escaped farmed

${ }^{*}$ Corresponding author: florian.sambraus@hi.no
Atlantic salmon has ranged from 38000 to 921000 per year between 2005 and 2015 (Directorate of Fisheries Norway 2016). This has caused concerns regarding genetic interactions with wild stocks (Glover et al. 2012), and highlights the incentives for the use of sterile salmon in commercial aquaculture (Benfey 2016). Although the production of triploid salmon

(C) The authors 2018. Open Access under Creative Commons by Attribution Licence. Use, distribution and reproduction are unrestricted. Authors and original publication must be credited. 
first started in the 1970s, implementation has been slow. The main concerns have been lower growth rates (Jungalwalla 1991, Friars et al. 2001, Taylor et al. 2013), reduced stress tolerance (Fraser et al. 2015) and increased mortality, particularly under suboptimal environmental conditions, when compared to diploids (Ojolick et al. 1995, Cotter et al. 2002, Hyndman et al. 2003b, Hansen et al. 2015, Sambraus et al. $2017 \mathrm{a}, \mathrm{b})$.

Most of the salmon grow-out phase takes place in seawater in floating net pens that have direct water exchange with the local environment. Therefore, the fish are exposed to large seasonal variations in water temperature that usually ranges between 2 and $19^{\circ} \mathrm{C}$ along the Norwegian coast (Oppedal et al. 2011). The lower and upper temperature limits for feeding in diploid Atlantic salmon are reported to be between 0 and 7 , and 22 and $28^{\circ} \mathrm{C}$, respectively (reviewed by Elliott \& Elliott 2010), while the thermal optimum is between 13 and $19^{\circ} \mathrm{C}$ (Handeland et al. 2008, Hevrøy et al. 2013). The temperature ranges occur due to the inverse relationship between optimum temperature and body size in salmonids (McCauley \& Huggins 1979). Previous studies have shown comparable growth rates in diploid and triploid Atlantic salmon during their first year at sea (Galbreath \& Thorgaard 1995, Leclercq et al. 2011, Fjelldal et al. 2016), but this may be dependent on water temperature. For example, Sambraus et al. (2017a) recently demonstrated that triploid Atlantic salmon post-smolts (300 to $900 \mathrm{~g}$ ) had higher feed intake than diploids at water temperatures between 3 and $9^{\circ} \mathrm{C}$, but fed less than diploids at 15 and $18^{\circ} \mathrm{C}$. To date, the thermal optimum of large triploid Atlantic salmon with regards to feed intake and growth is unknown.

A second environmental factor that may vary within open net pens is the concentration of oxygen $\left(\mathrm{mg} \mathrm{O}_{2} \mathrm{l}^{-1}\right)$ in the water, which usually correlates with temperature. The environmental conditions in the net pens sets the limit for physiological function and production performance of the fish, primarily through their effects on fish metabolism (Fry 1971). Low levels of $\mathrm{O}_{2}$ in the water will eventually lower aerobic capacity, nutrient digestion and growth. In commercial size net pens, the oxygen saturation $\left(\mathrm{O}_{2}\right.$ sat, \% of air saturation) has been found to vary between 30 and $130 \%$ (Crampton et al. 2003, Johansson et al. 2006, 2007). Under practical farming conditions, low $\mathrm{O}_{2}$ concentrations, hypoxia, is most prevalent during periods with high water temperature (Oppedal et al. 2011, Burt et al. 2012), when the solubility of oxygen is low and fish metabolism is high. The combination of high water temperature and low $\mathrm{O}_{2 \text { sat }}$ has been found to amplify the negative effect of triploidy on feed intake and growth in Atlantic salmon postsmolts, both under chronic (Hansen et al. 2015) and temporary reductions in $\mathrm{O}_{2 \text { sat }}$ (Sambraus et al. 2017a). Metabolic activity and hence oxygen demand is known to increase with temperature (Fry 1971) and decrease with increasing fish size and age (Forsberg 1994). Oxygen consumption has been documented in diploid post-smolts (Remen et al. 2012) and adult salmon (Lee et al. 2003) as well as in triploid post-smolts (Sambraus et al. 2017a). However, it is unknown how triploidy affects the response of large fish to reductions in $\mathrm{O}_{2}$ sat at different temperatures. Physiological and clinical parameters are important when considering temperature tolerance in large diploid and triploid Atlantic salmon. For instance, haematocrit, plasma glucose, lactate and ions, along with white muscle creatine phosphate (CrP), adenosine triphosphate (ATP) and glucose have shown a response to increasing temperature in diploid and triploid Atlantic salmon post-smolts (Sambraus et al. 2017a) and brook trout Salvelinus fontinalis (Hyndman et al. 2003a,b) that may be enhanced in larger fish at the same temperatures.

Another concern with triploid salmon are higher incidences of ocular cataracts compared to diploids (Wall \& Richards 1992, Taylor et al. 2015, Sambraus et al. 2017b). The pathology of this disorder in diploid salmon becomes more severe at high (Waagbø et al. 2010) and fluctuating (Bjerkås \& Bjørnestad 1999) water temperature as well as in periods of fast growth (Bjerkås et al. 2001, Waagbø et al. 2010). In salmonids, as visual feeders, severe cataracts and poor vision may reduce welfare and feed intake, and limit affected fish in reaching their growth potential (Breck \& Sveier 2001). Dietary histidine levels can mitigate cataract outbreaks in both ploidies, although the requirement is higher in triploids than diploids (Taylor et al. 2015, Sambraus et al. 2017b). The positive affect of histidine is associated with its metabolite $\mathrm{N}$-acetyl-histidine (NAH) that functions as an osmolyte (Rhodes et al. 2010) and potentially an antioxidant (Remø et al. 2011) in the lens. In commercial Atlantic salmon aquaculture, severe cataracts can result in substantial financial losses (Menzies et al. 2002).

Regarding a previous experiment on the temperature effects of diploid and triploid post-smolts (Sambraus et al. 2017a), large Atlantic salmon are expected to perform similarly to the earlier life stage, although may have a lower thermal optimum for feed intake. In order to reduce the impact of escaped farmed salmon on wild stocks, the use of sterile 
triploids is desirable. However, the industry may only convert to triploid Atlantic salmon if their performance is similar. The aim of the present study was to examine differences in performance parameters with an emphasis on commercial interest and the physiological status of large triploid Atlantic salmon compared to diploids. Both ploidies were exposed to a wide range of water temperatures, from 3 to $18^{\circ} \mathrm{C}$, with additional periods of reduced oxygen saturation, 70 instead of $100 \% \mathrm{O}_{2}$ sat, at 6 and $18^{\circ} \mathrm{C}$. We investigated parameters related to production performance, white muscle energy stores, blood chemistry and ocular health.

\section{MATERIALS AND METHODS}

\section{Fish stock and rearing conditions}

The experiment was conducted at the Institute of Marine Research (IMR), Matre, Norway and approved by the Norwegian Animal Research Authority, in accordance with prevailing animal welfare regulations.

Fish eggs were provided by Aquagen (Trondheim, Norway) on 3 November 2009 ( $\mathrm{n}=209700$ ). To induce triploidy, half of the eggs were subjected to hydrostatic pressure of 655 bar for $6 \mathrm{~min}$ and $15 \mathrm{~s}$ (TRC-APV, Aqua Pressure Vessel, TRC Hydraulics) at $37 \mathrm{~min}$ and $30 \mathrm{~s}$ after fertilisation at $8^{\circ} \mathrm{C}$. The eggs of each ploidy were incubated separately in incubation trays (Sterner 2003, Sterner Fish Tech) in an isolated (UV treatment) flow-through system under darkness. Hatching started on 5 February 2010, and was completed by 18 February. On 26 April 2010, the yolk sack larvae of each ploidy were put into three $1.5 \mathrm{~m}$ fibreglass tanks under continuous light. The fish were continuously fed with a commercial start feed (NUTRA ST 0.5, Skretting) that increased in size up to $1.5 \mathrm{~mm}$ (Skretting). On 22 July 2010, the fish from each tank were mixed within ploidy and transferred to single, green, circular $3 \mathrm{~m}$ fibreglass tanks. To allow the fish to smolt as yearling smolts, the photoperiod was switch from $24 \mathrm{~h}$ light:0 h dark to simulated natural on 1 October. On 27 October 2010, all fish were vaccinated (Minova 6 Vet., Norvax(r), Intervet International) and transferred to larger single, green, $5 \mathrm{~m}$ fibreglass tanks. On 28 March 2011, a subsample of 2500 fish of each ploidy was transferred into separate tanks of the same type and reared until the change to seawater on 10 May 2011. In seawater, the fish were reared under continuous light until transfer to the experimental tanks.
The mean temperature in the period from fertilisation to start-feeding was $4.9^{\circ} \mathrm{C}$. From start-feeding until the summer solstice (21 June 2010), the fish were reared in heated freshwater (mean $12.7^{\circ} \mathrm{C}$ ) and changed to ambient freshwater until seawater transfer (mean $7.9^{\circ} \mathrm{C}$, $\max .15 .3^{\circ} \mathrm{C}$, min. $3.0^{\circ} \mathrm{C}$ ). The ambient seawater temperature (10 May 2011 to 22 August 2012) ranged between 8.0 and $8.6^{\circ} \mathrm{C}$. The oxygen saturation in the outlet was kept above $80 \%$ $\mathrm{O}_{2 \text { sat }}$ from hatching until transfer to the experimental tanks.

Triploidy was verified by measuring erythrocytes prior to the experiment (Benfey et al. 1984). Ten randomly chosen red blood cells of each blood smear sampled from 80 diploid and 80 triploid fish were measured (Image-Pro Plus, version 4.0, Media Cybernetics). The individual red blood cell diameter in triploids (mean $20.8 \mu \mathrm{m}$, min. $19.8 \mu \mathrm{m}$ ) had a larger mean and the range did not overlap with that of diploids (mean $16.8 \mu \mathrm{m}$, max. $18.1 \mu \mathrm{m}$ ), suggesting triploidisation occurred with $100 \%$ efficiency.

\section{Experimental facilities}

On 23 August 2012, mixed sex Atlantic salmon ( $\mathrm{n}=120$ fish per ploidy) were measured for length and weight, and individually pit tagged (Trovan transponders ID 101, BTS Scandinavia) before being separated by ploidy and randomly distributed into 6 circular indoor tanks (40 fish per tank; 3 tanks per ploidy; $3 \mathrm{~m}$ diameter; $6300 \mathrm{l} ; 80 \mathrm{l} \mathrm{min}^{-1}$ ). During the acclimation period and the experiment, all tanks were exposed to $24 \mathrm{~h}$ continuous light (Philips, TL-D 36W/ 33-640). Customised computer software (SD Matre, Normatic) controlled and regulated flow (Promag W flow meters, Endress and Hauser), temperature (TST 487-1A2B temperature probes), salinity (Liquisys MCLM223/ 253 probes), oxygen (Oxyguard 420 probe, Oxyguard International) and automatic feeding (Arvo-Tec $\mathrm{T}$ drum 2000). Until the start of the experiment on 13 September 2012 (Day 1) the fish were given an acclimation period in $34 \%$ seawater $\left(9.3 \pm 1^{\circ} \mathrm{C}\right)$. Oxygen levels were mainly regulated by the water flow, although supported by supersaturated water $\left(400 \% \mathrm{O}_{2}\right)$. Oxygen probes in the outflow of each tank were air calibrated weekly, taking temperature changes and atmospheric pressure variations into account. All water parameters were continuously measured and recorded as a mean of 5 min intervals per tank. The oxygen saturation was kept at $100 \%$ in the outflow during normoxia. 


\section{Feeding and experimental design}

The fish were fed a commercial diet (Nutra Olympic $7 \mathrm{~mm}$, Skretting) twice a day for $30 \mathrm{~min}$ $(08: 30 h ; 14: 00 h)$, aiming for 10 to $20 \%$ overfeeding per meal to ensure satiation. A sieve positioned in the outflow of each tank from the start of feeding to 10 min post feeding collected uneaten pellets. The sieve was removed from the outflow and left to air dry for $10 \mathrm{~min}$ to let excessive water drip off, and the content was subsequently weighed. The daily feed intake per tank was calculated by considering the amount of food supplied and the dry matter content of air-dried feed as well as the amount of collected uneaten pellets and the dry matter content of those. Due to the varying stability of feed pellets at different water temperatures, a recovery rate (\%) of waterexposed pellets was included for each temperature the fish were exposed to (Helland et al. 1996).

Fifteen days after the start of the experiment, the temperature was decreased from 9 down to $6^{\circ} \mathrm{C}$ for $1 \mathrm{wk}$ and then decreased again down to $3^{\circ} \mathrm{C}$ for $1 \mathrm{wk}$ (Fig. 1). Thereafter, the temperature was increased by $3^{\circ} \mathrm{C}$ wk $^{-1}$ until it reached $18^{\circ} \mathrm{C}$. Temperature changes were induced by the automated system at night. One additional week each at $6^{\circ} \mathrm{C}$ (Days 37 to 42 ) and at $18^{\circ} \mathrm{C}$ (Days 72 to 77 ) were included during which the fish were subjected to hypoxia. The water $\mathrm{O}_{2}$ sat was decreased from $100 \%$ by $10 \% \mathrm{~d}^{-1}$ until $70 \% \mathrm{O}_{2}$ sat was reached and this was maintained for $3.5 \mathrm{~d}$ until sampling. Hypoxia was induced by reduc-

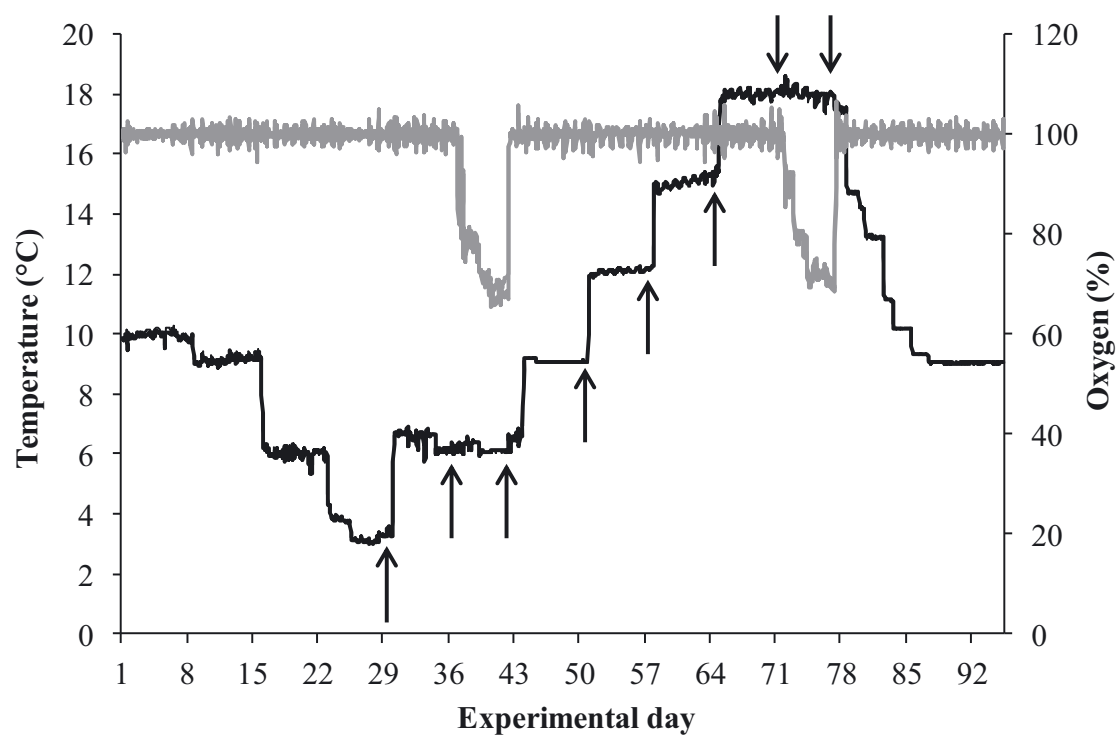

Fig. 1. Water temperature (black line) and water oxygen saturation (grey line; $\mathrm{n}=24$ measurements per day) in experimental tanks with large diploid and triploid Atlantic salmon Salmo salar in seawater. Arrows indicate the sampling time points ing the water inflow and closing the addition of supersaturated water. After both samplings at the hypoxic periods, the water $\mathrm{O}_{2}$ sat was again increased to $100 \%$ in the outflow. After the final sampling $\left(18_{\mathrm{h}}{ }^{\circ} \mathrm{C}\right.$, $\mathrm{h}$ : hypoxic conditions), the temperature gradually decreased from 18 to $9^{\circ} \mathrm{C}$ by $1^{\circ} \mathrm{C} \mathrm{d}^{-1}$ in order to examine how the fish recovered.

At the start of the experiment, 3 diploid and 1 triploid fish were removed due to lesions. During the experiment, 2 triploid fish did not recover from an anaesthetic bath after the sampling at $18^{\circ} \mathrm{C}$. These fish were excluded from mortality calculations.

\section{Sampling procedures}

At the start of the experiment on 13 September 2012, all fish were weighed, measured and examined for cataracts. Samplings for white muscle, blood and plasma were conducted postprandially at $3^{\circ} \mathrm{C}$ (Day 29), $6^{\circ} \mathrm{C}$ (Day 36), $6{ }_{\mathrm{h}}^{\circ} \mathrm{C}$ (hypoxia; Day 42 ), $9^{\circ} \mathrm{C}$ (Day 50), $12^{\circ} \mathrm{C}$ (Day 57), $15^{\circ} \mathrm{C}$ (Day 64), $18^{\circ} \mathrm{C}$ (Day 71) and $18_{\mathrm{h}}{ }^{\circ} \mathrm{C}$ (hypoxia; Day 77). In order to minimise fish stress and maintain their physiological parameters, the water level was reduced and all fish were lightly anesthetised (25 $\mathrm{mg} \mathrm{l}^{-1}$ Finquel®, Scanaqua) prior to netting individuals. After netting, each fish was killed by a blow to the head. A cooling pack stored at $-80^{\circ} \mathrm{C}$ was placed with light pressure on the left fillet side. With a heparinised syringe (Heparin LEO, LEO Pharma), a blood sample was drawn from the caudal vein and divided into subsamples. One part was instantly frozen in liquid nitrogen as whole blood, while the other was centrifuged for $2 \mathrm{~min}$ at $13000 \mathrm{rpm}(11228 \mathrm{~g})$ to allow blood and plasma to separate, which were subsequently separately frozen in liquid nitrogen. After the blood sample was drawn, the cooling unit was removed, and a sample of white muscle was taken from underneath the dorsal fin and immediately frozen in liquid nitrogen. Time from netting to flesh freezing was approximately $1 \mathrm{~min}$. All samples were finally stored at $-80^{\circ} \mathrm{C}$ until further analysis. The procedure was conducted with 3 fish per tank for each sampling. On Day 50, the sampled fish ( $\mathrm{n}=9$ per ploidy) were examined for cataracts, and on Day 71, an additional 9 fish per ploidy $(\mathrm{n}=18$ per ploidy) were examined for cataracts to 
allow for individual comparison to the start of the experiment. At these 2 sampling points, lenses were dissected and additional white muscle samples taken for lens and muscle-free basic amino acid analysis.

To avoid additional handling, the whole fish stock was only measured and weighed at tank stocking, the start of the experiment and at the last sampling point at $18_{\mathrm{h}}{ }^{\circ} \mathrm{C}$ (Day 77). After the start of the experiment, handling and stress was reduced to a minimum in order to let the fish behave and feed undisturbed throughout the temperature changes. The experiment was terminated on 17 December 2012 (Day 96).

\section{Measurements}

Growth and feed conversion ratio

Body mass (to $10 \mathrm{~g}$ ) and fork length (to $1 \mathrm{~cm}$ ) were measured for each sampled fish. The specific growth rate $\left(\mathrm{SGR}\right.$, growth \% $\left.\mathrm{d}^{-1}\right)$ was calculated as $\mathrm{SGR}=\left(\mathrm{e}^{q}\right.$ - 1) $\times 100$ (Houde \& Scheckter 1981), where $q=$ $\left[\ln \left(W_{2}\right)-\ln \left(W_{1}\right)\right]\left(t_{2}-t_{1}\right)^{-1}$ (Bagenal \& Tesch 1978). $W_{2}$ and $W_{1}$ represent the live body weight at time points $t_{2}$ (sampling) and $t_{1}$ (start of the experiment), respectively. The condition factor (CF) was calculated as $\mathrm{CF}$ $=$ weight $[\mathrm{g}] /$ length $^{3}[\mathrm{~cm}] \times 100$. The feed conversion ratio (FCR) was calculated as FCR = feed intake [g] / weight gain $[g]$.

Muscle preparation and analysis

(CrP, ATP, glycogen)

White muscle samples were directly transferred from $-80^{\circ} \mathrm{C}$ into a freeze-drying unit at $-55^{\circ} \mathrm{C}$ and dried for $3 \mathrm{~d}$. The dried samples were superficially cleaned of blood and thoroughly ground with mortar and pestle into a fine powder and again stored at $-80^{\circ} \mathrm{C}$ until analysis. CrP, ATP and glycogen were analysed as described by Solstorm et al. (2015). Briefly, for CrP and ATP analysis, perchloric acid was mixed with a sample of ground white muscle and immersed in an ultrasonic ice bath. The samples were mixed, neutralised and centrifuged, and the supernatant was filtered and transferred into HPLC glass vials for analysis that was performed instantly using a modified version of the method described by Sellevold et al. (1986) and Volonté et al. (2004). The samples were separated on a $\mathrm{C}_{18}$ HPLC column at $30^{\circ} \mathrm{C}$ and the mobile phase was set at a constant flow rate $\left(1.3 \mathrm{ml} \mathrm{min}^{-1}\right)$. The samples were recorded on a diode array at $215 \mathrm{~nm}$. Stock solutions were prepared in perchloric acid and diluted with the mobile phase to standard concentrations ( $\mathrm{CrP} 0.400 \mu \mathrm{mol} \mathrm{ml}{ }^{-1}$, ATP $0.190 \mu \mathrm{mol} \mathrm{ml} \mathrm{m}^{-1}$ ). The standard curves were created by increasing the injection volumes from 10 to $50 \mu \mathrm{l}$. After dilution with the mobile phase, the solution was stable for $30 \mathrm{~min}$.

For glycogen extraction, $\mathrm{HCl}$ was added to a freeze-dried and ground white muscle sample and hydrolysed. The samples were centrifuged, and the supernatant was separated and frozen at $-80^{\circ} \mathrm{C}$. Another sample of freeze-dried, ground white muscle was mixed with $\mathrm{HCl}$ and thoroughly mixed to extract free glucose. After centrifugation, the supernatant was separated and frozen at $-80^{\circ} \mathrm{C}$. After thawing, all samples were neutralised and diluted in buffer to ensure a neutral pH balance. Analysis was performed in duplicates with the Cayman's Glucose Colorimetric Assay Kit (Cayman Chemical Company). The individual results were adjusted for exact ground sample weight and dilution volumes. Glycogen was calculated by subtracting free glucose concentrations. Due to a technical failure, the samples from the $6_{\mathrm{h}}$ and $9^{\circ} \mathrm{C}$ samplings were lost.

\section{Haematology}

Haematocrit was measured by centrifuging whole blood heparinised capillary tubes for $2 \mathrm{~min}$ (StatSpin® Multipurpose Centrifuge). Whole blood haemoglobin concentrations were analysed with the QuantiChrom $^{\mathrm{TM}}$ Haemoglobin Assay Kit (BioAssay Systems). Plasma cortisol was analysed with Cortisol Parameter Assay Kits (Cortisol ELISA, RE 52061, IBL). Plasma ion levels $\left(\mathrm{Na}^{+}, \mathrm{K}^{+}, \mathrm{Cl}^{-}\right)$were detected by ion selective electrodes, plasma triacylglycerols (TAG), glucose and lactate were analysed with standard kits using a COBAS c111 auto analyser (Roche Diagnostics). A pH meter (Radiometer PHM92 with PHC 3395-8 plasma electrode) was used to determine plasma $\mathrm{pH}$.

\section{Cataracts, and lens and muscle-free amino acids}

Cataracts were detected with a Kowa SL-15 slitlamp biomicroscope (Kowa Company) and scored according to the grading scale of Wall \& Richards (1992). Depending on the degree of opacification, each lens was given a score from 0 to 4 and each fish a score from 0 to 8 . Lens NAH was analysed as described by Breck (2004), adapted from O'Dowd et al. (1990), by reverse phase HPLC (Waters Corpora- 
tion). Lens and white muscle-free basic amino acids were analysed according to Breck et al. (2005) by amino ninhydrin detection (Amersham Pharmacia Biotech) with Biochrom 20 plus (Biochrome).

\section{Oxygen consumption}

The measurements for oxygen consumption were performed as described by Sambraus et al. (2017a). In brief, oxygen consumption was estimated using the experimental tanks as open respirometers. The days for measuring the oxygen consumption were the first and the second last day of each temperature period. On those days, the inflow of oxygenated water was stopped for $30 \mathrm{~min}$ (11:15 to 11:45 h), leading to a gradual decline in oxygen content. Oxygen consumption rate $\left(\mathrm{MO}_{2}\right)$ was estimated from the equation:

$\mathrm{MO}_{2 t}=$

$\left(\mathrm{Vol} \cdot \mathrm{Sol} \cdot \frac{\mathrm{Sat}_{t}-\mathrm{Sat}_{t-1}}{\delta t \cdot 100}+\mathrm{Flow} \cdot \mathrm{Sol} \cdot \frac{100-\mathrm{Sat}_{t}}{100}+\mathrm{O}_{2 \text { flux }}\right) \cdot$ biomass $^{-1}$

where Vol is the tank volume (l, excluding fish volume), Sol is the solubility of oxygen at the prevailing temperature and conductivity $\left(\mathrm{mg} \mathrm{l}^{-1}\right)$, and $\mathrm{Sat}_{t}$ is the oxygen saturation (\%) at time $t$ (the average saturation for $1 \mathrm{~min}$ intervals was used, $\delta t=1 \mathrm{~min}$ ). Flow is the rate at which new aerated water replaces the tank water $\left(1 \mathrm{~min}^{-1}\right)$. Biomass is the estimated biomass of fish $(\mathrm{kg})$ in the tank on the day of oxygen consumption measurements. The biomass for each tank is calculated by dividing the accumulated feed intake until the day of measurement by the individual FCR for each tank and then adding the measured tank biomass from the start of the experiment minus dead and sampled fish. Only the average consumption rate of the last $15 \mathrm{~min}$ of the $30 \mathrm{~min}$ period was used for the calculation. The oxygen flux $\left(\mathrm{O}_{2 \text { flux }}\right)$ over the water surface during the progressive decline in oxygen was modeled as:

$$
\mathrm{O}_{2 \text { flux }}=k \cdot\left(100-\mathrm{Sat}_{t}\right) \cdot \mathrm{Sol} \cdot \frac{\mathrm{Vol}}{100}
$$

where $k$ is the diffusion constant. The value of $k$ was estimated by first oxygen-stripping the water in fishless tanks using $\mathrm{N}_{2}$ gas and then measuring the $\mathrm{O}_{2 \text { sat }}$ increase as water exchanged with normoxic water at exchange rates matching those of the fish tanks (Remen et al. 2013). By inserting the $\mathrm{O}_{2}$ flux equation into the $M \mathrm{O}_{2}$ equation and letting $M \mathrm{O}_{2}=$ 0 , the increase in oxygen saturation after oxygenstripping was modelled with different values of $k$.
The value of $k=0.00135$ maximised the correlation between the observed and modelled increase in oxygen saturation after oxygen-stripping $\left(\mathrm{R}^{2}=\right.$ 0.9997).

\section{Statistical analyses}

All statistical analyses were conducted using Statistica $^{\mathrm{TM}} 12.0$ (Dell). Fish weight, length, condition factor and cataract score at stocking and at the start of the experiment were tested by 2-way nested ANOVAs with tank replicate (random effect) nested in ploidy. The effect of ploidy on growth performance, feed intake, white muscle energy parameters, blood and blood plasma, amino acids and lens-related parameters were tested using nested ANOVA designs with tank replicate as random effect, nested in ploidy and temperature period. Significant nested ANOVAs were followed by factorial ANOVA designs with ploidy and temperature period as categorical variables to detect possible interactions and followed by Student-Newman-Keuls (SNK) post hoc tests to detect differences within and between diploids and triploids at the different temperatures. A significance level of $5 \%(\mathrm{p}<0.05)$ was used for all tests. All data were tested for normality using a KolmogorovSmirnov test prior to statistical analysis. Homoscedasticity of all data was inspected visually. Two variables, plasma triglycerides and plasma lactate, were log-transformed in order to ensure normality and homoscedasticity.

\section{RESULTS}

\section{Effect of temperature and $\mathrm{O}_{2}$ sat on feed intake, oxygen consumption and growth}

At stocking, there was no difference between both ploidies in body weight (2N: $2253 \pm 34$ g; $3 \mathrm{~N}: 2248 \pm$ $56 \mathrm{~g})$ or length $(2 \mathrm{~N}: 57.3 \pm 0.3 \mathrm{~cm} ; 3 \mathrm{~N}: 58.1 \pm 0.5 \mathrm{~cm})$, but triploids had a significantly lower condition factor than diploids $(2 \mathrm{~N}: 1.18 \pm 0.00 ; 3 \mathrm{~N}: 1.14 \pm 0.00 ; \mathrm{p}<$ $0.001 ; 2$-way nested ANOVA). At the end of the acclimation period $\left(9^{\circ} \mathrm{C}\right)$, triploids were significantly heavier (2N: $2307 \pm 29$ g; $3 \mathrm{~N}$ : $2494 \pm 63$ g; $\mathrm{p}=0.015)$, longer $(2 \mathrm{~N}$ : $57.7 \pm 0.2 \mathrm{~cm} ; 3 \mathrm{~N}: 59.0 \pm 0.5 \mathrm{~cm} ; \mathrm{p}=$ $0.002)$ and had a higher condition factor $(2 \mathrm{~N}: 1.18 \pm$ $0.00 ; 3 \mathrm{~N}: 1.21 \pm 0.00 ; \mathrm{p}=0.022,2$-way nested ANOVA) than diploids.

There was an effect of temperature and an interaction between temperature and ploidy on mean daily 
Table 1. p-values of growth performance and condition (specific growth rate, length growth, condition factor, mean daily feed intake, oxygen consumption), white muscle (creatine phosphate [CrP], ATP, glycogen), blood (haemoglobin, haematocrit) and plasma parameters (cortisol, chloride, sodium, triacylglycerol, glucose, lactate and pH) in Atlantic salmon Salmo salar for Figs. 2 to 7. Each parameter was tested in a nested ANOVA design (temperature $[\mathrm{T}]$, ploidy [P]) with tank as random factor, nested in ploidy and sampling point (temperature). Significant nested ANOVAs were followed by factorial ANOVAs $(\mathrm{T} \times \mathrm{P})$ to detect possible interactions between the treatments. DM: dry mass. Values in bold indicate a significant effect $(p<0.05)$

\begin{tabular}{|c|c|c|c|}
\hline \multirow[t]{2}{*}{ Parameter } & \multirow{2}{*}{$\begin{array}{c}\text { Nested ANOVA } \\
\mathrm{T}\end{array}$} & \multicolumn{2}{|c|}{ Factorial ANOVA } \\
\hline & & $\mathrm{P}$ & $\mathrm{T} \times \mathrm{P}$ \\
\hline Mean daily feed intake (\% biomass) & $<0.001$ & 0.689 & $<0.001$ \\
\hline Oxygen consumption (mg $\mathrm{O}_{2} \mathrm{~kg}^{-1} \mathrm{~min}^{-1}$ ) & $<0.001$ & 0.268 & 0.820 \\
\hline Specific growth rate (\% growth $\left.\mathrm{d}^{-1}\right)$ & $<0.001$ & $<0.001$ & 0.021 \\
\hline Length growth $\left(\mathrm{mm} \mathrm{d}^{-1}\right)$ & $<0.001$ & $<0.001$ & 0.409 \\
\hline Condition factor & $<0.001$ & 0.033 & $<0.001$ \\
\hline $\mathrm{CrP}\left(\mu \mathrm{mol} \mathrm{g} \mathrm{DM}{ }^{-1}\right)$ & $<0.001$ & $<0.001$ & 0.985 \\
\hline ATP $\left(\mu \mathrm{mol} \mathrm{g} \mathrm{DM^{-1 } )}\right.$ & $<0.001$ & $<0.001$ & 0.569 \\
\hline Glycogen $\left(\mu \mathrm{mol} \mathrm{g} \mathrm{DM}{ }^{-1}\right)$ & $<0.001$ & 0.011 & 0.011 \\
\hline Haemoglobin $\left(\mathrm{mg} \mathrm{dl}^{-1}\right)$ & $<0.001$ & $<0.001$ & 0.152 \\
\hline Haematocrit $(\%)$ & $<0.001$ & $<0.001$ & 0.197 \\
\hline Cortisol (ng ml$\left.{ }^{-1}\right)$ & $<0.001$ & 0.582 & $<0.001$ \\
\hline Chloride $\left(\mathrm{mmol} \mathrm{l}^{-1}\right)$ & $<0.001$ & 0.329 & 0.538 \\
\hline Sodium $\left(\mathrm{mmol} \mathrm{l}^{-1}\right)$ & $<0.001$ & 0.991 & 0.370 \\
\hline Potassium $\left(\mathrm{mmol} \mathrm{l}^{-1}\right)$ & 0.851 & 0.748 & 0.549 \\
\hline Triacylglycerol $\left(\mathrm{mmol} \mathrm{l}^{-1}\right)$ & $<0.001$ & 0.150 & 0.304 \\
\hline Glucose $\left(\mathrm{mmol} \mathrm{l}^{-1}\right)$ & $<0.001$ & 0.038 & 0.085 \\
\hline Lactate $\left(\mathrm{mg} \mathrm{dl}^{-1}\right)$ & $<0.001$ & 0.065 & 0.893 \\
\hline $\mathrm{pH}$ & $<0.001$ & 0.560 & 0.360 \\
\hline
\end{tabular}

There was a significant effect of temperature and ploidy on the SGR (Fig. 3A), length growth (mm d $\mathrm{d}^{-1}$; Fig. 3B) and the condition factor (Fig. 3C), and of the interaction between temperature and ploidy on the SGR and the condition factor (Table 1). Triploids had higher SGRs than diploids from the start of the experiment until the second sampling at $6^{\circ} \mathrm{C}$ (Fig. 3A), and faster length growth than diploids at $18^{\circ} \mathrm{C}$. For all remaining fish that were measured at $18_{\mathrm{h}}{ }^{\circ} \mathrm{C}$, there was no effect of ploidy on the SGR in diploid and triploid males (nested ANOVA, $p=0.814$ ) and females $(\mathrm{p}=$ 0.721 ). The condition factor was significantly affected by temperature and ploidy, and there was an interaction between both parameters (Table 1). Triploids had a significant higher condition factor than diploids at 3 and $9^{\circ} \mathrm{C}$.

Mortality was low with only 2 diploid fish during the acclimation period and 1 diploid $\left(15^{\circ} \mathrm{C}\right)$ and 1 triploid $\left(18^{\circ} \mathrm{C}\right)$ fish during the experiment. feed intake (Table 1). Excluding the hypoxic periods, feeding increased from 3 to $12^{\circ} \mathrm{C}$ and decreased with further increasing temperature in both ploidies (Fig. 2A). Triploids had higher feed intake than diploids at the initial $9^{\circ} \mathrm{C}$ period and the second period at $6^{\circ} \mathrm{C}$, while diploids fed more at 15 and $18^{\circ} \mathrm{C}$, when feeding dropped more in triploids than diploids.

Reducing $\mathrm{O}_{2}$ sat from 100 to $70 \%$ at $6^{\circ} \mathrm{C}$ had no negative effect on the feed intake in either ploidy (Fig. 2A; see Fig. S1A in the Supplement at www.int-res.com/articles/suppl/q010p157_supp.pdf). However, the same reduction in $\mathrm{O}_{2 \text { sat }}$ at $18^{\circ} \mathrm{C}$ caused a significant decrease in feed intake in both ploidies that was more pronounced in diploids than in triploids (Fig. 2A; see Fig. S1B in the Supplement). In the recovery period after $18_{\mathrm{h}}{ }^{\circ} \mathrm{C}$, there was no effect of ploidy on feed intake (see Fig. S1C in the Supplement). The feed conversion ratio from the start of the experiment to the final sampling was $1.00 \pm 0.03$ and $1.01 \pm 0.02$ in diploids and triploids, respectively.

The oxygen consumption rate (Fig. 2B) was affected by temperature (Table 1 ) and increased from 3 to $9^{\circ} \mathrm{C}$ and again to $15^{\circ} \mathrm{C}$ in both ploidies.

\section{White muscle energy analyses}

White muscle energy phosphates (CrP and ATP) and glycogen were significantly affected by temperature period and ploidy (Fig. 4A-C, Table 1). Muscle $\mathrm{CrP}$ concentrations decreased from 3 to $6^{\circ} \mathrm{C}$ in both ploidies, and also from 6 to $18_{\mathrm{h}}{ }^{\circ} \mathrm{C}$ in triploids. ATP levels in diploids were not affected by temperature, whereas triploid fish had higher levels at 3 and $12^{\circ} \mathrm{C}$ compared to $18^{\circ} \mathrm{C}$, and levels at $15^{\circ} \mathrm{C}$ were lower compared to diploids. There was an effect of the interaction between temperature and ploidy on muscle glycogen and levels at $12^{\circ} \mathrm{C}$ were higher in diploids than triploids (Table 1, Fig. 4C).

\section{Haematology}

There was a significant effect of temperature and ploidy on blood haemoglobin (Fig. 5A) and haematocrit (Fig. 5B, Table 1). With increasing temperature, haemoglobin increased in diploids $\left(3\right.$ to $15^{\circ} \mathrm{C}$ and 9 to $18^{\circ} \mathrm{C}$ ), but not triploids. Haematocrit increased in both ploidies, although this was more amplified in diploids than triploids. Diploids had higher haemoglo- 

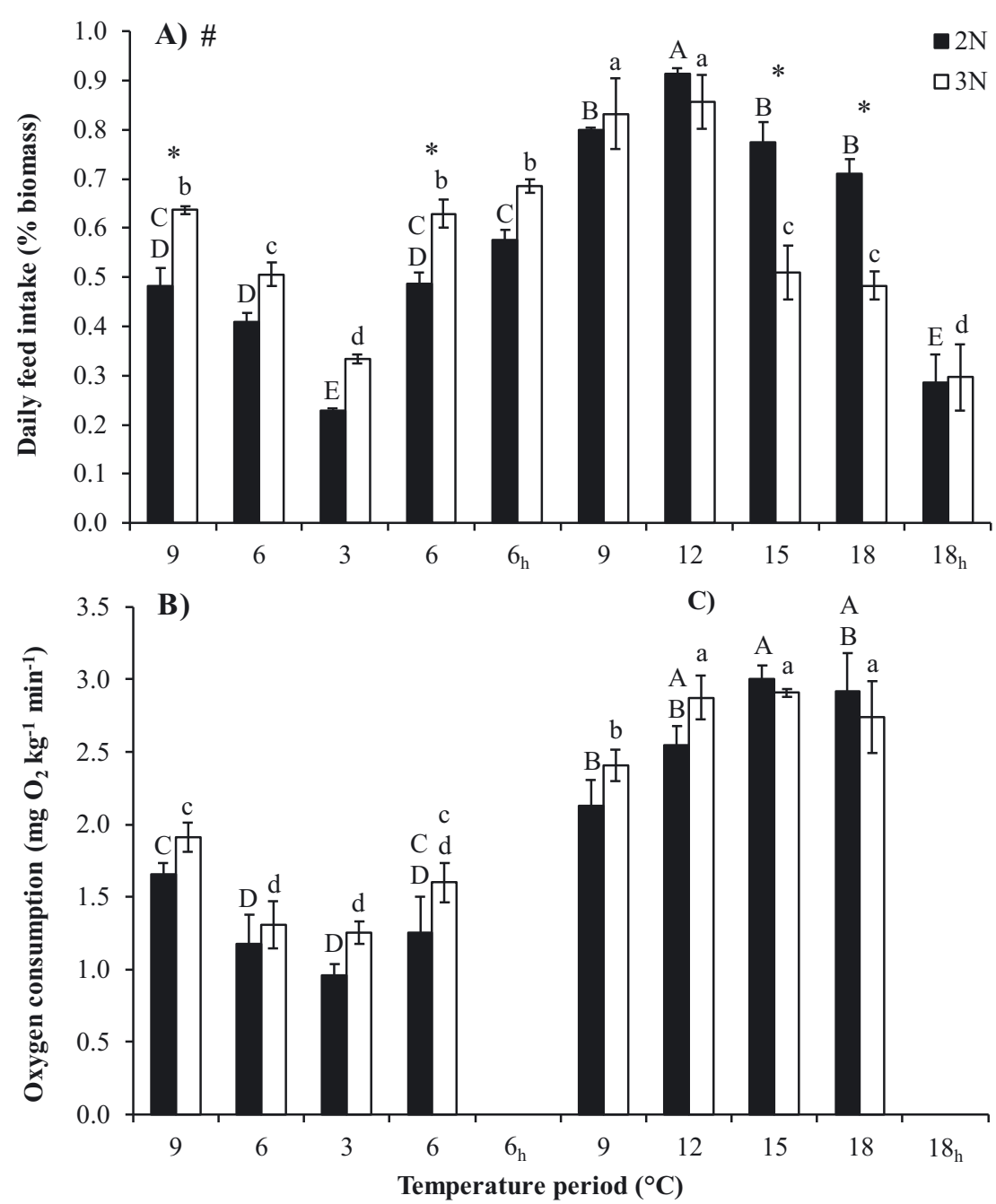

Fig. 2. Mean \pm SE (A) daily feed intake and (B) oxygen consumption in triplicate groups of large diploid and triploid Atlantic salmon Salmo salar in seawater. The oxygen consumption was not measured during hypoxic periods $(\mathrm{h})$. Different uppercase (lowercase) letters indicate significant differences between temperature periods in diploids (triploids). *Significant difference between ploidies at the specific sampling point (Student-Newman-Keuls, $\mathrm{p}<0.05$ ); \#: significant interaction between temperature period and ploidies (factorial ANOVA, $\mathrm{p}<0.05)$ from 15 to $18^{\circ} \mathrm{C}$ and more so in diploids, resulting in higher levels at $18^{\circ} \mathrm{C}$. When $\mathrm{O}_{2}$ sat was decreased from 100 to $70 \%$ at $18^{\circ} \mathrm{C}$, ploidies differed as plasma cortisol in triploids increased. Plasma chloride was lowest in both groups at $9^{\circ} \mathrm{C}$ and levels in triploids were higher during hypoxia at $18^{\circ} \mathrm{C}$ compared to normoxia. Plasma sodium increased from 3 to $6^{\circ} \mathrm{C}$ in both ploidies and from 15 to $18^{\circ} \mathrm{C}$ in diploids. During hypoxia, levels in both groups were lower compared to normoxia at $6^{\circ} \mathrm{C}$. Plasma potassium was not affected by temperature period or ploidy and the values ranged between $2.67\left(15^{\circ} \mathrm{C}\right)$ and $3.00 \mathrm{mM}\left(18^{\circ} \mathrm{C}\right)(2.82 \pm 0.10 \mathrm{mM}$; mean $\pm \mathrm{SD})$ in diploids and $2.74\left(12^{\circ} \mathrm{C}\right)$ and $3.04 \mathrm{mM}\left(18_{\mathrm{h}}{ }^{\circ} \mathrm{C}\right)(2.85 \pm 0.12 \mathrm{mM})$ in triploids (data not shown).

There was a significant effect of temperature on plasma TAG (Fig. 7A), glucose (Fig. 7B), lactate (Fig. 7C) and $\mathrm{pH}$ (Fig. 7D), and a significant effect of ploidy on plasma glucose (Table 1). In triploids, TAG was higher at 6 and $9^{\circ} \mathrm{C}$ compared to 15 and $18^{\circ} \mathrm{C}$. Plasma glucose in triploids increased from normoxia to hypoxia at $18^{\circ} \mathrm{C}$ and levels were higher compared to diploids. Plasma lactate increased from 15 to $18^{\circ} \mathrm{C}$ in diploids and from 15 to $18_{\mathrm{h}}{ }^{\circ} \mathrm{C}$ in triploids. The plasma $\mathrm{pH}$ in both ploidies was higher at $9^{\circ} \mathrm{C}$ than 6 and $12^{\circ} \mathrm{C}$, and lower at $18^{\circ} \mathrm{C}$ than $15^{\circ} \mathrm{C}$ in triploids. Compared to normoxia, hypoxia resulted in a lower blood $\mathrm{pH}$ at $6^{\circ} \mathrm{C}$ in triploids and $18^{\circ} \mathrm{C}$ in diploids. bin concentrations than triploids at $18^{\circ} \mathrm{C}$ and higher haematocrit at 15 and $18_{\mathrm{h}}{ }^{\circ} \mathrm{C}$. Both ploidies had a significant increase in haemoglobin and haematocrit when $\mathrm{O}_{2}$ sat was decreased from 100 to $70 \%$ at $18^{\circ} \mathrm{C}$ (Fig. 5A,B).

\section{Plasma clinical chemistry}

There was a significant effect of temperature on plasma cortisol (Fig. 6A), chloride (Fig. 6B) and sodium (Fig. 6C, Table 1). Plasma cortisol increased in both ploidies when the temperature increased

\section{Cataract development, and lens and muscle-free amino acid composition}

At the start of the experiment, triploids had a significantly higher mean cataract score compared to diploids (nested ANOVA, $\mathrm{p}<0.001$ ). Diploids ( $\mathrm{n}=$ 118) had a mean score of $0.5 \pm 0.0$, and the mean score of affected individuals was $1.2 \pm 0.1$, representing $40.3 \%$ of the diploid population. The respective scores in triploids $(\mathrm{n}=120)$ were $2.1 \pm 0.1$ and $2.5 \pm$ $0.1(85.8 \%)$. The cataract assessment at the end of the $9^{\circ} \mathrm{C}$ period on Day 50 ( $\mathrm{n}=9$ per ploidy), using a subsample of the fish that were evaluated at the start 

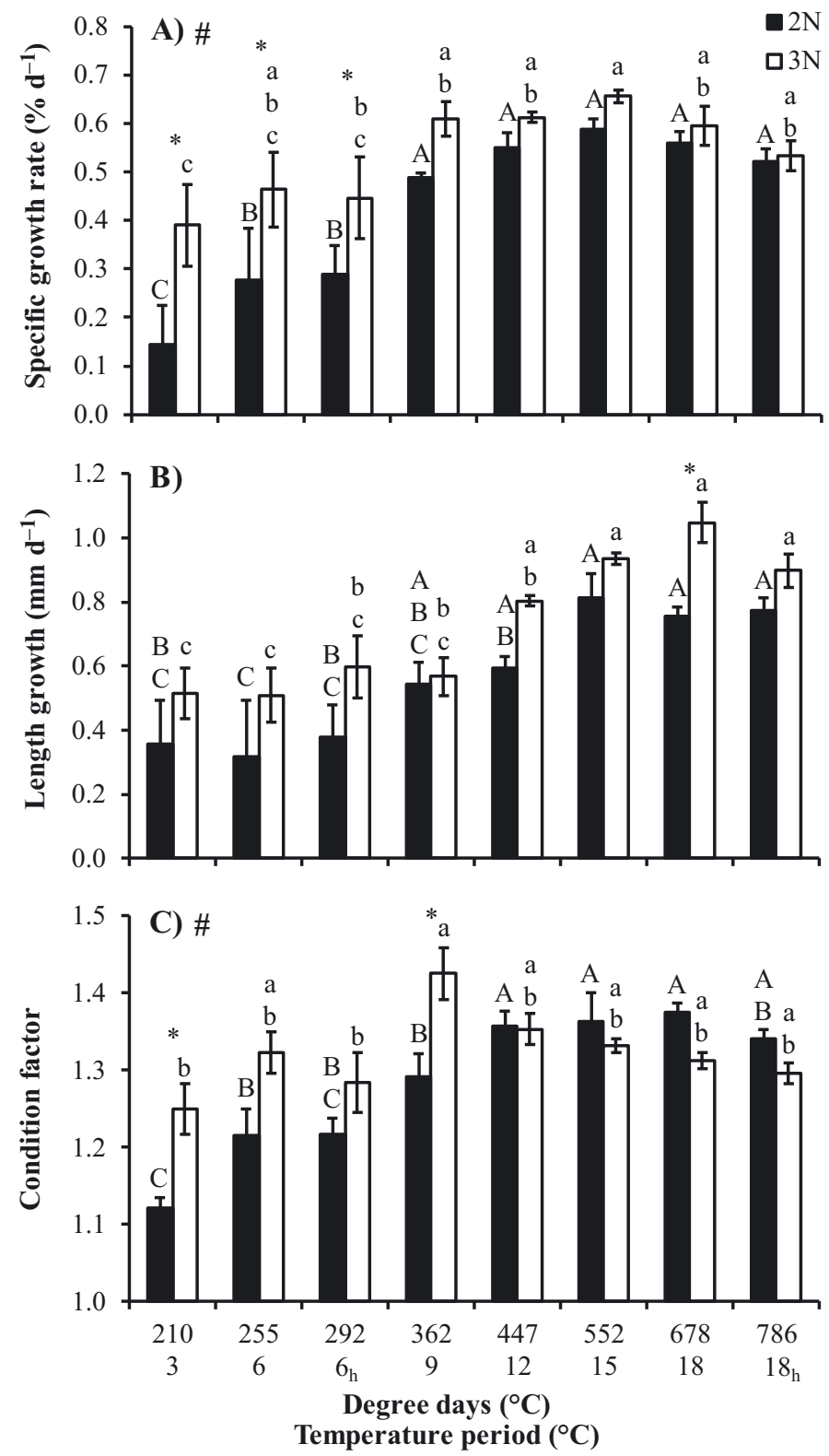

Fig. 3. Mean \pm SE (A) specific growth rate, (B) length growth and (C) condition factor of large diploid and triploid Atlantic salmon Salmo salar in seawater. See Fig. 2 for explanation of symbols

of the experiment, showed that diploid individuals had a lower cataract score compared to the start, while triploids had an increase in the sum score from $2.1 \pm 0.2$ to $3.0 \pm 0.6$ (Table 2 ). A new subsample on Day 71 ( $\mathrm{n}=18$ per ploidy) revealed an individual increase in cataract score in triploids from $2.5 \pm 0.3$ at the start of the experiment to $3.1 \pm 0.2$, in contrast to a reduced mean cataract score in diploids $(0.5 \pm 0.1$ to $0.4 \pm 0.1$ ). The cataract occurrence on Day 50 was positively correlated with the individual SGR in tri-
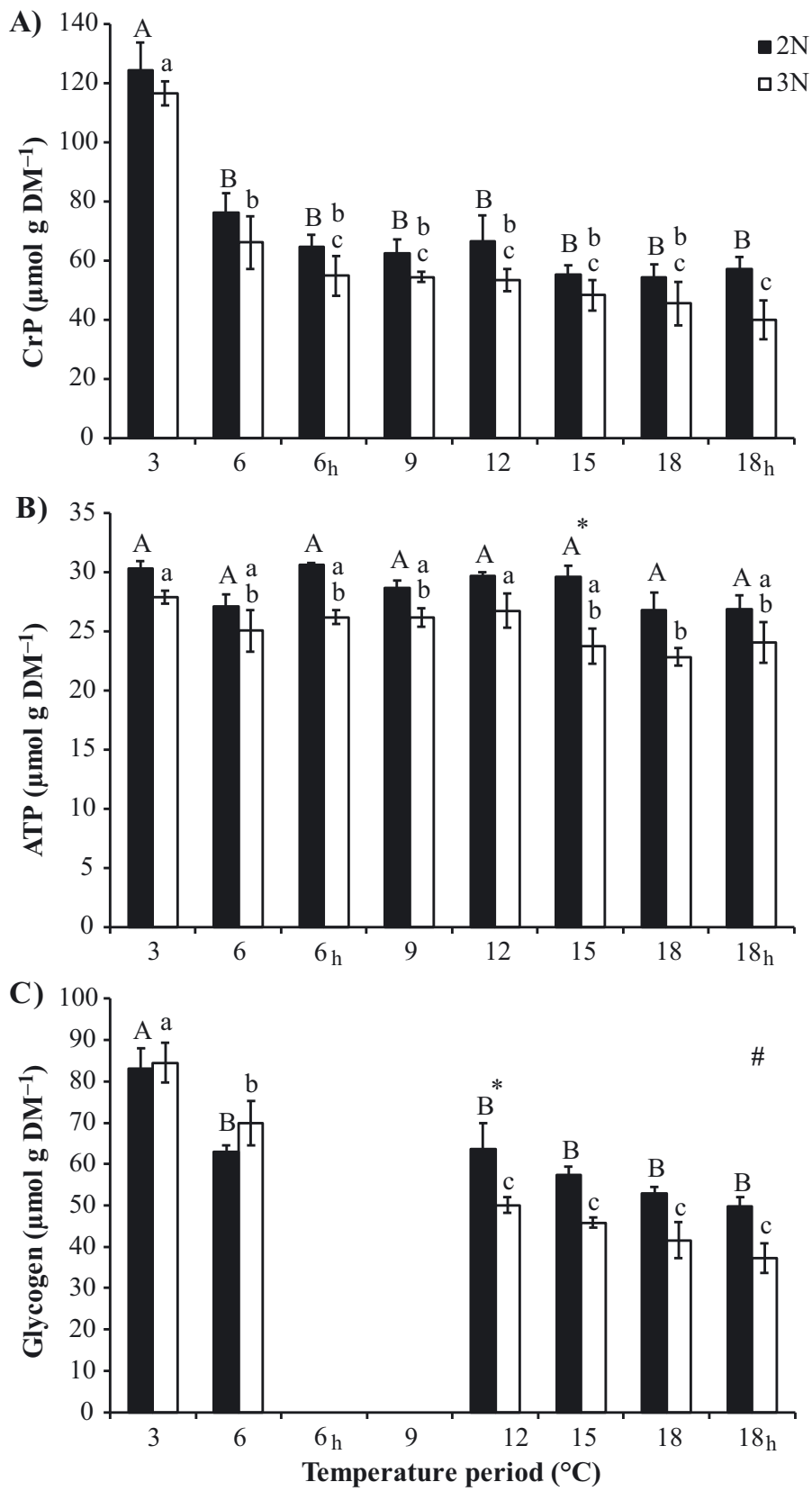

Fig. 4. Mean \pm SE white muscle (A) creatine phosphate (CrP), (B) adenosine triphosphate (ATP) and (C) glycogen levels in large diploid and triploid Atlantic salmon Salmo salar in seawater. n.d.: no data due to technical failure. DM: dry mass. See Fig. 2 for explanation of symbols

ploids $\left(y=11.727 x-4.2965 ; R^{2}=0.5583\right)$. There was no difference in lens histidine and NAH between ploidies at both samplings (Table 2).

In triploids, histidine was significantly elevated among white muscle-free basic amino acids at both sampling points (Table 2). Carnosine was significantly higher in triploids than diploids at $9^{\circ} \mathrm{C}$ on Day 50, but not at $18^{\circ} \mathrm{C}$ on Day 71 . There was no sig- 

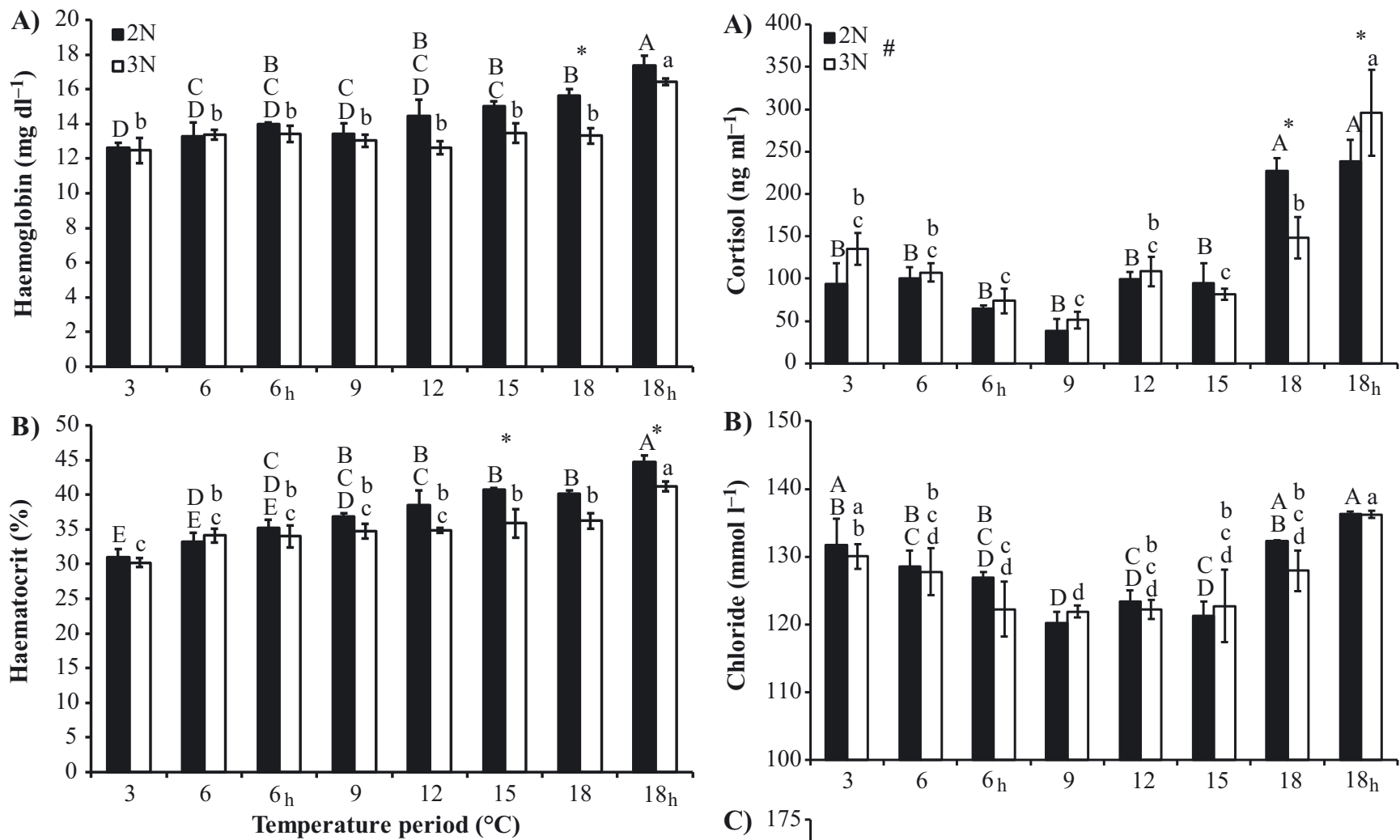

Fig. 5. Mean \pm SE blood (A) haemoglobin and (B) haematocrit levels in large diploid and triploid Atlantic salmon Salmo salar in seawater. See Fig. 2 for explanation of symbols

nificant difference between ploidies in the remaining amino acids at either sampling point (Table 2).

\section{DISCUSSION}

Our objective was to determine how large triploid Atlantic salmon perform under a broad range of temperatures and periods of reduced oxygen compared to diploids. For many of our growth and physiological indicators, we found that triploids performed as well as or better than diploids between 3 and $12^{\circ} \mathrm{C}$, including under hypoxia. At and above $15^{\circ} \mathrm{C}$, triploids performed worse compared to diploids with regards to feed intake and showed initial signs of physiological stress and limitations, although without mortalities, during the most challenging period. Therefore, farming triploids would appear a viable alternative to diploids in areas where temperatures do not exceed $15^{\circ} \mathrm{C}$ for prolonged periods.

We found triploids had greater feed intake than diploids at lower temperatures, but lower feed intake at higher temperatures. The same ploidy effect with

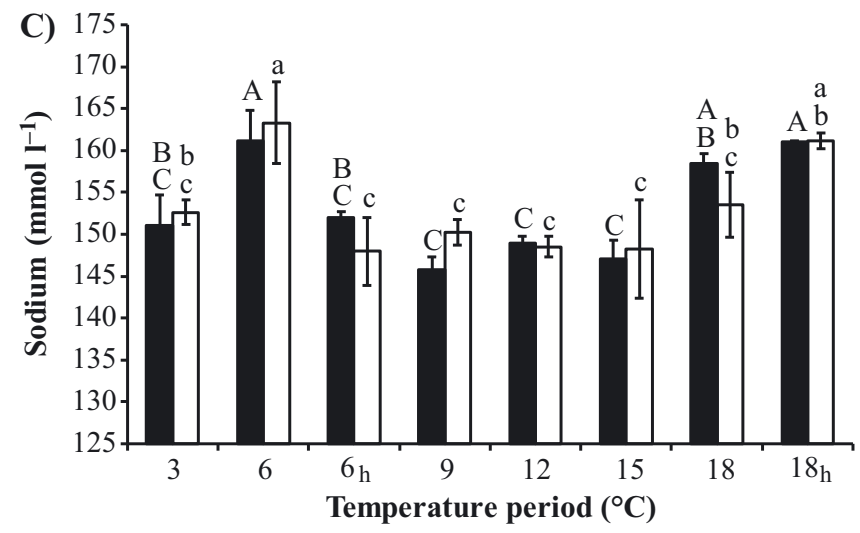

Fig. 6. Mean \pm SE plasma (A) cortisol, (B) chloride and (C) sodium levels in large diploid and triploid Atlantic salmon Salmo salar in seawater. See Fig. 2 for explanation of symbols

temperatures has been observed before, but appears more pronounced in the current study on large fish compared to previous work on post-smolts (Hansen et al. 2015, Sambraus et al. 2017a). This is most likely due to the narrower thermal window of larger compared to juvenile fish (Pörtner \& Farrell 2008). We found no ploidy effect on the FCR, similar to previous studies with salmonids (Habicht et al. 1994, Yamamoto \& Iida 1994, Hansen et al. 2015), although Fraser et al. (2013) reported a lower biological FCR in triploids when reared in seacages. Feed conversion in triploids may differ at different temperatures. This 

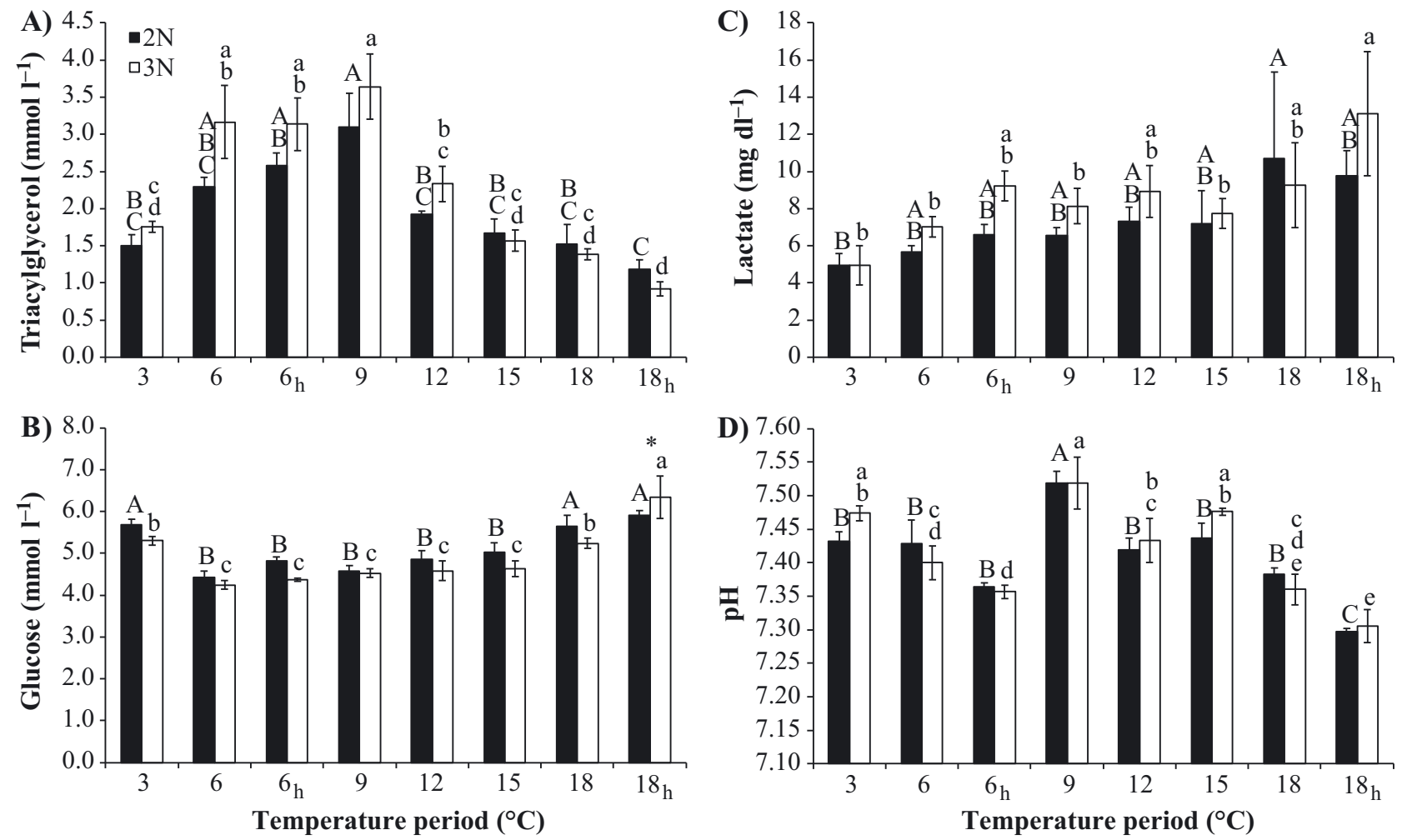

Fig. 7. Mean \pm SE plasma (A) triacylglycerol, (B) glucose, (C) lactate and (D) pH levels in large diploid and triploid Atlantic salmon Salmo salar in seawater. See Fig. 2 for explanation of symbols

Table 2. Cataract score (0 to 8) and mean \pm SE lens and muscle-free basic amino acids $\left(\mu m o l \mathrm{~g}^{-1}\right)$ on Day $50\left(9^{\circ} \mathrm{C}\right)$ and $71\left(18^{\circ} \mathrm{C}\right)$ in triplicate groups of diploid and triploid Atlantic salmon Salmo salar in seawater. The cataract score for Day 0 is the mean score for the same fish. NAH: N-acetyl-histidine. p-values in bold indicate significantly different means between ploidies on the given day $(p<0.05)$

\begin{tabular}{|c|c|c|c|c|c|c|c|}
\hline \multirow[t]{2}{*}{ Sample } & \multirow[t]{2}{*}{ Parameter } & \multicolumn{3}{|c|}{$\longrightarrow$ Day $50 \longrightarrow$} & \multicolumn{3}{|c|}{ - Day $71-$} \\
\hline & & Diploid & Triploid & $\mathrm{p}$-value & Diploid & Triploid & $\mathrm{p}$-value \\
\hline \multirow[t]{4}{*}{ Lens } & Cataract score (Day 0) & $0.3 \pm 0.2$ & $2.1 \pm 0.2$ & $<0.001$ & $0.5 \pm 0.1$ & $2.5 \pm 0.3$ & $<0.001$ \\
\hline & Cataract score & $0.0 \pm 0.0$ & $3.0 \pm 0.6$ & $<0.001$ & $0.4 \pm 0.1$ & $3.1 \pm 0.2$ & $<0.001$ \\
\hline & Histidine & $0.70 \pm 0.10$ & $0.83 \pm 0.08$ & 0.820 & $0.74 \pm 0.12$ & $0.80 \pm 0.07$ & 0.670 \\
\hline & NAH & $7.48 \pm 0.62$ & $6.75 \pm 0.53$ & 0.436 & $7.69 \pm 0.71$ & $6.59 \pm 0.70$ & 0.644 \\
\hline \multirow[t]{6}{*}{ Muscle } & Histidine & $0.55 \pm 0.12$ & $0.94 \pm 0.07$ & 0.006 & $0.75 \pm 0.03$ & $1.08 \pm 0.06$ & 0.024 \\
\hline & Anserine & $15.0 \pm 0.4$ & $15.1 \pm 0.2$ & 0.973 & $14.9 \pm 0.3$ & $14.6 \pm 0.2$ & 0.520 \\
\hline & Carnosine & $0.51 \pm 0.07$ & $0.77 \pm 0.09$ & 0.008 & $0.19 \pm 0.02$ & $0.13 \pm 0.01$ & 0.501 \\
\hline & Ornithine & $0.04 \pm 0.00$ & $0.04 \pm 0.01$ & 0.527 & $0.03 \pm 0.01$ & $0.04 \pm 0.01$ & 0.695 \\
\hline & Arginine & $0.19 \pm 0.01$ & $0.24 \pm 0.02$ & 0.134 & $0.13 \pm 0.00$ & $0.16 \pm 0.02$ & 0.246 \\
\hline & Lysine & $0.59 \pm 0.03$ & $0.88 \pm 0.16$ & 0.120 & $0.73 \pm 0.11$ & $0.96 \pm 0.05$ & 0.261 \\
\hline
\end{tabular}

could not be measured under the present setup, but it has been documented in diploid Atlantic salmon (Handeland et al. 2008), indicating a need for further research on feeding efficiency.

The specific growth rate reflected the feed intake and the difference between ploidies decreased with an increasing number of degree days at higher water temperatures. This was concomitant with a shift from a higher to lower mean condition factor in triploids. Triploidy in salmonids is often associated with a lower condition factor during the seawater phase compared to diploids (Leclercq et al. 2011, Taylor et 
al. 2015, Fjelldal et al. 2016, Smedley et al. 2016). The reasons for this may be multifactorial and can include weight loss due to smoltification (Sambraus et al. $2017 b)$ or, as observed in the present study, increasing length growth when weight growth is stagnating or decreasing. Nevertheless, the present data on feed intake, growth rate and condition factor show that triploids can outgrow diploid Atlantic salmon at cold and moderate water temperatures.

In the present study, large triploids had the highest feed intake at 9 and $12^{\circ} \mathrm{C}$ compared to $12^{\circ} \mathrm{C}$ in diploids. The optimum temperature for growth in diploid Atlantic salmon has been found to be $14^{\circ} \mathrm{C}$ in post-smolts (170 to $300 \mathrm{~g}$, Handeland et al. 2008)) and $\leq 13^{\circ} \mathrm{C}$ in fish of $1.6 \mathrm{~kg}$ (Hevrøy et al. 2013), compared to $12^{\circ} \mathrm{C}$ in triploids (Sambraus et al. 2017a). The present findings not only confirm a lower temperature optimum in triploids, but are also in accordance with a negative relationship between optimal temperature for feed intake and fish size.

Current theory suggests that the upper temperature limit in fish is determined by metabolic processes. Higher temperature increases metabolism and oxygen consumption, and hence reduces the scope for activity. Once routine metabolism is higher than the capacity for oxygen uptake, the capacity for feeding and hence the scope for growth decreases. Further, when energy costs exceed energy intake, the fish may become hypoxic if feeding continues; therefore, feeding activity is reduced (Claireaux et al. 2000, Hevrøy et al. 2012, Remen et al. 2012). The more pronounced drop in feed intake from 12 to $15^{\circ} \mathrm{C}$ in triploids compared to diploids in the present study also points to a lower temperature optimum in triploids. Although the feed intake in triploids was only two-thirds of that of diploids at 15 and $18^{\circ} \mathrm{C}$, both ploidies had similar oxygen consumption rates at those temperatures. As triploids also had lower levels of muscle glycogen than diploids at $\geq 12^{\circ} \mathrm{C}$, this indicates that, under a regime of increasing temperature, triploids begin to utilise endogenous energy sources at an earlier point, i.e. at a colder temperature, than diploids. Atkins \& Benfey (2008) demonstrated that the routine metabolic rate in triploid Atlantic salmon is higher at low temperatures and lower at high temperatures when compared to diploids. Although we found no differences in the present study, we did see a similar trend that may however also be influenced by feed intake and specific dynamic action, respectively.

Lowering the $\mathrm{O}_{2 \text { sat }}$ from 100 to $70 \%$ had no negative effects on feeding at $6^{\circ} \mathrm{C}$, only at $18^{\circ} \mathrm{C}$, when both ploidies significantly reduced feeding but eventually fed at similar rates during hypoxia and the recovery period at $100 \% \mathrm{O}_{2}$ sat thereafter (see Fig. $\mathrm{S} 1$ in the Supplement). This contrasts with previous work where hypoxic conditions at similar high temperatures reduced feeding more in triploid than diploid postsmolts (Hansen et al. 2015, Sambraus et al. 2017a). Furthermore, there was no mortality recorded in the present study when environmental conditions were challenging compared to the high mortality in other studies that exposed triploid salmonids to suboptimal conditions such as high temperature and/or reduced oxygen (Ojolick et al. 1995, Hyndman et al. 2003b, Hansen et al. 2015, Sambraus et al. 2017a). This may indicate an increased tolerance to hypoxia at later life stages in triploids or solely the fact that the intensity in the present experiment $\left(70 \% \mathrm{O}_{2 \text { sat }}\right)$ was lower compared to the chronic $\left(70 \% \mathrm{O}_{2 \text { sat }}\right)$ or more intense exposure $\left(60 \% \mathrm{O}_{2 \text { sat }}\right)$ to hypoxia, or the higher temperatures in the studies mentioned above.

Triploid salmon had significantly lower concentrations of white muscle energy phosphates compared to diploids. This would result in a reduced ability to cope with exercise in triploids (Hyndman et al. 2003b). Triploid salmon may have limited capacity to up-regulate $\mathrm{CrP}$ directly and/or the enzyme creatine kinase to produce sufficient $\mathrm{CrP}$ when ATP is available. Further, there was no hypoxia effect in either ploidy on these parameters at 6 or $18^{\circ} \mathrm{C}$, as previously found by Sambraus et al. (2017a). Triploid Atlantic salmon post-smolts also responded with decreasing muscle $\mathrm{CrP}$ concentrations at high temperatures $\left(18^{\circ} \mathrm{C}\right)$, although the exposure to hypoxia $\left(60 \% \mathrm{O}_{2 \text { sat }}\right)$ had no further effect (Sambraus et al. 2017a). Muscle glycogen decreased in both ploidies with increasing temperature and was higher in diploids at water temperatures of $12^{\circ} \mathrm{C}$ and above. The observed decrease in muscle glycogen between 6 and $18^{\circ} \mathrm{C}$ in triploids is of the same order of magnitude as that observed in triploid post-smolts within the same temperature range (Sambraus et al. 2017a). Temperature also had an effect on white muscle glycogen concentrations in resting triploid brook trout that had approximately $12 \%$ less glycogen at 19 than $9^{\circ} \mathrm{C}$ (Hyndman et al. 2003a,b). It appears that at cold temperatures and low metabolism, triploids successfully maintain muscle glycogen. However, at higher temperatures, the metabolism may utilise more, especially at times when feed intake in triploids is lower than in diploids.

There was a temperature and ploidy effect on blood haemoglobin and haematocrit in which diploids had higher concentrations than triploids with increasing water temperature. This has implications for the oxygen carrying capacity and responds to a reduced metabolic scope in triploids at high temperatures as 
previously suggested for triploid chinook salmon Oncorhynchus tshawytscha (Bernier et al. 2004). In the literature, blood haemoglobin concentrations in triploid salmonids have been reported to be both equal (Stillwell \& Benfey 1994, 1996) and lower (Benfey \& Sutterlin 1984, Small \& Randall 1989, Yamamoto \& Iida 1994, Kobayashi et al. 2009) compared to diploids, as has the blood-oxygen affinity (Graham et al. 1985, Verhille \& Farrell 2012). However, lower blood haemoglobin concentrations in triploids, as measured particularly at high water temperatures in the present study, ultimately limits oxygen transport to the tissues. Because efficient ATP synthesis is highly dependent on an oxygen-rich aerobic environment, this may be a cause for lower ATP and subsequently $\mathrm{CrP}$ levels in triploids. These factors make triploids susceptible to warm temperatures and may explain increased mortality in previous studies with such conditions (e.g. Ojolick et al. 1995, Hyndman et al. 2003b, Hansen et al. 2015, Sambraus et al. 2017a).

Under normoxic conditions, plasma lactate concentrations were similar in both ploidies, but lactate tended to be higher in triploids during hypoxia. Triploidy has been found to have little to no effect on plasma lactate in brook trout (Hyndman et al. 2003a) and Atlantic salmon (Sadler et al. 2000, Fraser et al. 2014, Sambraus et al. 2017a). The large variation in plasma lactate levels in triploids at $18^{\circ} \mathrm{C}$ and hypoxia gives reason to assume that there may be a wide variation in tolerance within the population, families or individuals. It has been shown that family has a significant effect on different performance parameters (Friars et al. 2001) and also on the tolerance level of temperature and hypoxia (Anttila et al. 2013) in salmonids. As triploid families perform similarly well as diploids (Taylor et al. 2013), it may be possible to selectively breed triploid families that are more tolerant to hypoxia.

Growth rates, haematological and plasma parameters, and the lack of considerable mortalities, support the assumption that the fish in the present study were somewhat stressed, although within a zone of physiological tolerance. Nonetheless, the primary (plasma cortisol) and secondary (plasma glucose) stress responses were significantly higher in triploids compared to diploids at the combination of high temperatures and hypoxia. The stress responses in diploids and triploids have been reported to be similar after stressful events in brook trout (Biron \& Benfey 1994, Benfey \& Biron 2000) and Atlantic salmon (Sadler et al. 2001, Fraser et al. 2014), in experiments conducted at moderate water temperatures and following physical stress. It is possible that high mortality in previous experiments, where triploid salmonids were exposed to challenging chronic or acute conditions, is attributable to a combination of high stress and altered energy metabolism and haematology when the water temperature is high.

The occurrence of cataracts at the start of the experiment and also the development of lens opacities thereafter was higher in triploids than diploids, which is in accordance with previous studies (Leclercq et al. 2011, Taylor et al. 2013, 2015, Sambraus et al. 2017b). This did not only include the incidence of cataract-affected fish, which was higher in triploids, but also the severity when compared to diploids. The fact that both diploid subsamples had a lower cataract score during the experiment compared to the start of the experiment suggests a reversible type of cataract that may have been induced by an osmotic disturbance (e.g. due to anaesthetics) at the initial sampling. Causes of cataracts in Atlantic salmon can be multifactorial, but identified risk factors include smoltification (Waagbø et al. 1996, Bjerkås \& Sveier 2004), increasing or elevated seawater temperatures (Bjerkås \& Bjørnestad 1999, Bjerkås et al. 2001), accelerated growth (Bjerkås et al. 2001, Breck \& Sveier 2001, Waagbø et al. 2010) and nutritional aspects (Bjerkås et al. 2006). Cataracts were more frequently observed in Atlantic salmon in the 1990s after the removal of blood meal from the diets (Wall 1998). Blood meal is rich in the amino acid histidine, and omitting blood meal from the diets reduced the concentration of dietary histidine and thereby tissue imidazoles, such as the cataract-mitigating NAH in the lens (Rhodes et al. 2010, Waagbø et al. 2010). In this study, there was no significant effect of ploidy on either lens histidine or lens NAH concentrations, although mean lens NAH concentrations were over $10 \%$ lower in triploids at both sampling points. Low levels of lens NAH have been shown to correlate with cataract formation in both diploid and triploid Atlantic salmon (Waagbø et al. 2010, Taylor et al. 2015), and it is possible that the small difference in lens NAH between ploidies led to a cataract increase in triploids but not diploids. Severe cataract formation has negative effects on feed intake and growth (Breck \& Sveier 2001, Ersdal et al. 2001, Breck et al. 2003, Taylor et al. 2015), and therefore not only affects fish welfare, but also economical aspects (Menzies et al. 2002). Both ploidies in the present experiment were fed commercial diets for diploids, but it has been shown that triploid salmon have an altered nutritional requirement for certain nutrients compared to diploids (e.g. phosphorous: Fjelldal et al. 2016, histidine: Tay- 
lor et al. 2015, Sambraus et al. 2017b) which may have made triploids more susceptible to cataracts than diploids. With regards to histidine, the demand for adjusted triploid diets particularly applies at times when nutrient requirement is increased e.g. in periods of fast growth or at warm water temperatures (Sambraus et al. 2017b). It is probable that the cataract development in triploids would have been reduced if a diet with elevated concentrations of histidine was fed.

\section{CONCLUSION}

The findings of the present study demonstrate that large triploid Atlantic salmon feed and grow equally well or better than diploids at cold and moderate water temperatures, but less so than diploids at 15 and $18^{\circ} \mathrm{C}$. When exposed to $70 \%$ oxygen saturation at 6 and $18^{\circ} \mathrm{C}$, feed intake in triploids was higher than or similar to diploids and no mortalities occurred. This is important for the aquaculture industry to find suitable locations for the grow-out of triploid Atlantic salmon. Triploids had generally less muscle energy stores and, with increasing water temperature, lower haemoglobin and haematocrit levels than diploids. This may impair fish performance and result in mortality under more severe environmental conditions than the ones tested in the present study. Most of the physiological parameters tested did not indicate a significant disadvantage of triploidy in responding to increasing temperature and reduced levels of dissolved oxygen. The low overall mortality and lack of mortality during hypoxia at high temperatures contrast with other studies, but suggest that large triploid salmon are, within thresholds, more tolerant to $\mathrm{O}_{2 \text { sat }}$ fluctuations compared to earlier life stages and thus may substitute diploid Atlantic salmon on a commercial scale.

Acknowledgements. The authors thank the staff of the Institute of Marine Research, Matre and Anita Birkenes (NIFES) for excellent technical assistance and 3 anonymous reviewers for helpful comments to improve the manuscript. This study was funded by the Fiskeri- og Havbruksnæringens Forskningsfond project (FHF, 900723) 'Solving Bottlenecks in Triploid Salmon Production - A Way to Strengthen the Sustainability of the Salmon Aquaculture Industry' from the Research Council of Norway (NRC, 216197).

\section{LITERATURE CITED}

Anttila K, Dhillon RS, Boulding EG, Farrell AP and others (2013) Variation in temperature tolerance among families of Atlantic salmon (Salmo salar) is associated with hypoxia tolerance, ventricle size and myoglobin level. J Exp Biol 216:1183-1190

Atkins ME, Benfey TJ (2008) Effect of acclimation temperature on routine metabolic rate in triploid salmonids. Comp Biochem Physiol A Mol Integr Physiol 149:157-161

Bagenal TB, Tesch FW (1978) Age and growth. Methods for assessment of fish production in fresh waters, IBP Handbook No. 3, 3rd edn. Blackwell, Oxford, p 101-136

Benfey TJ (2016) Effectiveness of triploidy as a management tool for reproductive containment of farmed fish: Atlantic salmon (Salmo salar) as a case study. Rev Aquacult 8: 264-282

Benfey TJ, Biron M (2000) Acute stress response in triploid rainbow trout (Oncorhynchus mykiss) and brook trout (Salvelinus fontinalis). Aquaculture 184:167-176

Benfey TJ, Sutterlin AJ (1984) $\mathrm{O}_{2}$ utilization by triploid landlocked Atlantic salmon (Salmo salar L.). Aquaculture 42: 69-73

Benfey TJ, Sutterlin AM, Thompson RJ (1984) Use of erythrocyte measurements to identify triploid salmonids. Can J Fish Aquat Sci 41:980-984

* Bernier NJ, Brauner CJ, Heath JW, Randall DJ (2004) Oxygen and carbon dioxide transport during sustained exercise in diploid and triploid Chinook salmon (Oncorhynchus tshawytscha). Can J Fish Aquat Sci 61:1797-1805

Biron M, Benfey TJ (1994) Cortisol, glucose and hematocrit changes during acute stress, cohort sampling, and the diel cycle in diploid and triploid brook trout (Salvelinus fontinalis Mitchill). Fish Physiol Biochem 13:153-160

Bjerkås E, Bjørnestad E (1999) Is there a connection between rapid fluctuation in water temperature and cataract development in the Atlantic salmon (Salmo salar L)? Bull Eur Assoc Fish Pathol 19:166-169

* Bjerkås E, Sveier H (2004) The influence of nutritional and environmental factors on osmoregulation and cataracts in Atlantic salmon (Salmo salar L). Aquaculture 235: 101-122

Bjerkås E, Bjørnestad E, Breck O, Waagbø R (2001) Water temperature regimes affect cataract development in smolting Atlantic salmon, Salmo salar L. J Fish Dis 24: 281-291

Bjerkås E, Breck O, Waagbø R (2006) The role of nutrition in cataract formation in farmed fish. Perspect Agric Vet Sci Nutr Nat Resour 1:1-16

Breck O (2004) Histidine nutrition and cataract development in Atlantic salmon, Salmo salar L. PhD thesis, University of Bergen/National Institute of Nutrition and Seafood Research (NIFES)

Breck O, Sveier H (2001) Growth and cataract development in two groups of Atlantic salmon (Salmo salar L.) post smolts transferred to sea with a four week interval. Bull Eur Assoc Fish Pathol 21:91-103

* Breck O, Bjerkås E, Campbell P, Arnesen P, Haldorsen P, Waagbø R (2003) Cataract preventative role of mammalian blood meal, histidine, iron and zinc in diets for Atlantic salmon (Salmo salar L.) of different strains. Aquacult Nutr 9:341-350

* Breck O, Bjerkås E, Campbell P, Rhodes JD, Sanderson J, Waagbø R (2005) Histidine nutrition and genotype affect cataract development in Atlantic salmon, Salmo salar L. J Fish Dis 28:357-371

Burt K, Hamoutene D, Mabrouk G, Lang C and others (2012) Environmental conditions and occurrence of hypoxia within production cages of Atlantic salmon on the south coast of Newfoundland. Aquacult Res 43:607-620 
Claireaux G, Webber DM, Lagardère JP, Kerr SR (2000) Influence of water temperature and oxygenation on the aerobic metabolic scope of Atlantic cod (Gadus morhua). J Sea Res 44:257-265

Cotter D, O'Donovan V, Drumm A, Roche Nult, Ling EN, Wilkins NP (2002) Comparison of freshwater and marine performances of all-female diploid and triploid Atlantic salmon (Salmo salar L.). Aquac Res 33:43-53

Crampton V, Hølland PM, Bergheim A, Gausen M, Næss A (2003) Oxygen effects on caged salmon. Fish Farm Int (June edn.) p 26-27

Directorate of Fisheries Norway (2016) Statistikk akvakultur. Available at: www.fiskeridir.no/Akvakultur/Statistikkakvakultur/Roemmingsstatistikk (accessed on 12 July 2016)

Elliott JM, Elliott JA (2010) Temperature requirements of Atlantic salmon Salmo salar, brown trout Salmo trutta and Arctic charr Salvelinus alpinus:predicting the effects of climate change. J Fish Biol 77:1793-1817

Ersdal C, Midtlyng PJ, Jarp J (2001) An epidemiological study of cataracts in seawater farmed Atlantic salmon Salmo salar. Dis Aquat Org 45:229-236

Fjelldal PG, Hansen TJ, Lock EJ, Wargelius A and others (2016) Increased dietary phosphorous [sic] prevents vertebral deformities in triploid Atlantic salmon (Salmo salar L.). Aquacult Nutr 22:72-90

Forsberg OI (1994) Modelling oxygen consumption rates of post-smolt Atlantic salmon in commercial-scale, landbased farms. Aquacult Int 2:180-196

Fraser TWK, Hansen T, Skjæraasen JE, Mayer I, Sambraus F, Fjelldal PG (2013) The effect of triploidy on the culture performance, deformity prevalence, and heart morphology in Atlantic salmon. Aquaculture 416-417:255-264

Fraser TWK, Mayer I, Skjæraasen JE, Hansen T, Fjelldal PG (2014) The effect of triploidy on the efficacy and physiological response to anesthesia with MS 222 and isoeugenol in Atlantic salmon post-smolts. Aquacult Int 22: 1347-1359

Fraser TWK, Vindas MA, Fjelldal PG, Winberg S and others (2015) Increased reactivity and monoamine dysregulation following stress in triploid Atlantic salmon (Salmo salar). Comp Biochem Physiol A Mol Integr Physiol 185: 125-131

Friars GW, McMillan I, Quinton VM, O'Flynn FM, McGeachy SA, Benfey TJ (2001) Family differences in relative growth of diploid and triploid Atlantic salmon Salmo salar L. Aquaculture 192:23-29

F Fry FEJ (1971) The effect of environmental factors on the physiology of fish. Fish Physiol 6:1-98

* Galbreath PF, Thorgaard GH (1995) Saltwater performance of all-female triploid Atlantic salmon. Aquaculture 138: 77-85

Glover KA, Quintela M, Wennevik V, Besnier F, Sørvik AG, Skaala Ø (2012) Three decades of farmed escapees in the wild: a spatio-temporal analysis of Atlantic salmon population genetic structure throughout Norway. PLOS ONE $7: \mathrm{e} 43129$

Graham MS, Fletcher GI, Benfey TJ (1985) Effect of triploidy on blood oxygen content of Atlantic salmon. Aquaculture 50:133-139

Habicht C, Seeb JE, Gates RB, Brock IR, Olito CA (1994) Triploid coho salmon outperform diploid and triploid hybrids between coho salmon and Chinook salmon during their first year. Can J Fish Aquat Sci 51:31-37

* Handeland SO, Imsland AK, Stefansson SO (2008) The effect of temperature and fish size on growth, feed intake, food conversion efficiency and stomach evacuation rate of Atlantic salmon post-smolts. Aquaculture 283:36-42

* Hansen TJ, Olsen RE, Stien L, Oppedal F and others (2015) Effect of water oxygen level on performance of diploid and triploid Atlantic salmon post-smolts reared at high temperature. Aquaculture 435:354-360

*Helland SJ, Grisdale-Helland B, Nerland S (1996) A simple method for the measurement of daily feed intake of groups of fish in tanks. Aquaculture 139:157-163

*Hevrøy EM, Waagbø R, Torstensen BE, Takle H and others (2012) Ghrelin is involved in voluntary anorexia in Atlantic salmon raised at elevated sea temperatures. Gen Comp Endocrinol 175:118-134

Hevrøy EM, Hunskår C, de Gelder S, Shimizu M and others (2013) GH-IGF system regulation of attenuated muscle growth and lipolysis in Atlantic salmon reared at elevated sea temperatures. J Comp Physiol B 183:243-259

Houde ED, Scheckter RC (1981) Growth rates, rations and cohort consumption of marine fish larvae in relation to prey concentration. Rapp P-V Réun Cons Int Explor Mer 178:441-453

*Hyndman CA, Kieffer JD, Benfey TJ (2003a) The physiological response of diploid and triploid brook trout to exhaustive exercise. Comp Biochem Physiol A Mol Integr Physiol 134:167-179

* Hyndman CA, Kieffer JD, Benfey TJ (2003b) Physiology and survival of triploid brook trout following exhaustive exercise in warm water. Aquaculture 221:629-643

* Johansson D, Ruohonen K, Kiessling A, Oppedal F, Stiansen JE, Kelly M, Juell JE (2006) Effect of environmental factors on swimming depth preferences of Atlantic salmon (Salmo salar L.) and temporal and spatial variations in oxygen levels in sea cages at a fjord site. Aquaculture 254:594-605

Johansson D, Juell JE, Oppedal F, Stiansen JE, Ruohonen K (2007) The influence of the pycnocline and cage resistance on current flow, oxygen flux and swimming behaviour of Atlantic salmon (Salmo salar L.) in production cages. Aquaculture 265:271-287

Jungalwalla PJ (1991) Production of non-maturing Atlantic salmon in Tasmania. Can Tech Rep Fish Aquat Sci 1789: 47-71

Kobayashi T, Fushiki S, Ueno K (2009) Physiological response of triploid rainbow trout to exhaustive exercise. Suisan Zoshoku 57:361-370

* Leclercq E, Taylor JF, Fison D, Fjelldal PG, Diez-Padrisa M, Hansen T, Migaud H (2011) Comparative seawater performance and deformity prevalence in out-of-season diploid and triploid Atlantic salmon (Salmo salar) postsmolts. Comp Biochem Physiol A Mol Integr Physiol 158: 116-125

Lee CG, Farrell AP, Lotto A, MacNutt MJ, Hinch SG, Healey $\mathrm{MC}$ (2003) The effect of temperature on swimming performance and oxygen consumption in adult sockeye (Oncorhynchus nerka) and coho (O. kisutch) salmon stocks. J Exp Biol 206:3239-3251

*McCauley RW, Huggins NW (1979) Ontogenetic and nonthermal seasonal effects on thermal preferenda of fish. Am Zool 19:267-271

Menzies FD, Crockford T, Breck O, Midtlyng PJ (2002) Estimation of direct costs associated with cataracts in farmed Atlantic salmon (Salmo salar). Bull Eur Assoc Fish Pathol $22: 27-32$ 
O'Dowd JJ, Cairns MT, Trainor M, Robins DJ, Miller DJ (1990) Analysis of carnosine, homocarnosine, and other histidyl derivatives in rat brain. J Neurochem 55:446-452

Ojolick EJ, Cusack R, Benfey TJ, Kerr SR (1995) Survival and growth of all-female diploid and triploid rainbow trout (Oncorhynchus mykiss) reared at chronic high temperature. Aquaculture 131:177-187

* Oppedal F, Dempster T, Stien LH (2011) Environmental drivers of Atlantic salmon behaviour in sea-cages: a review. Aquaculture 311:1-18

Pörtner HO, Farrell AP (2008) Physiology and climate change. Science 322:690-692

Kemen M, Oppedal F, Torgersen T, Imsland AI, Olsen RE (2012) Effects of cyclic environmental hypoxia on physiology and feed intake of post-smolt Atlantic salmon: initial responses and acclimation. Aquaculture 326-329: 148-155

Remen M, Oppedal F, Imsland AK, Olsen RE, Torgersen T (2013) Hypoxia tolerance thresholds for post-smolt Atlantic salmon: dependency of temperature and hypoxia acclimation. Aquaculture 416-417:41-47

* Remø SC, Olsvik PA, Torstensen BE, Amlund H, Breck O, Waagbø R (2011) Susceptibility of Atlantic salmon lenses to hydrogen peroxide oxidation ex vivo after being fed diets with vegetable oil and methylmercury. Exp Eye Res 92:414-424

* Rhodes JD, Breck O, Waagbo R, Bjerkas E, Sanderson J (2010) N-acetylhistidine, a novel osmolyte in the lens of Atlantic salmon (Salmo salar L.). Am J Physiol Regul Integr Comp Physiol 299:R1075-R1081

Sadler J, Wells RMG, Pankhurst PM, Pankhurst NW (2000) Blood oxygen transport, rheology and haematological responses to confinement stress in diploid and triploid Atlantic salmon, Salmo salar. Aquaculture 184:349-361

Sadler J, Pankhurst PM, King HR (2001) High prevalence of skeletal deformity and reduced gill surface area in triploid Atlantic salmon (Salmo salar L.). Aquaculture 198:369-386

Sambraus F, Olsen RE, Remen M, Hansen TJ, Torgersen T, Fjelldal PG (2017a) Water temperature and oxygen: the effect of triploidy on performance and metabolism in farmed Atlantic salmon (Salmo salar L.) post-smolts. Aquaculture 473:1-12

Sambraus F, Fjelldal PG, Remø SC, Hevrøy EM and others (2017b) Water temperature and dietary histidine affect cataract formation in Atlantic salmon (Salmo salar L.) diploid and triploid yearling smolt. J Fish Dis 40:1195-1212

Sellevold OFM, Jynge P, Aarstad K (1986) High performance liquid chromatography: a rapid isocratic method for determination of creatine compounds and adenine nucleotides in myocardial tissue. J Mol Cell Cardiol 18: 517-527

Small SA, Randall DJ (1989) Effects of triploidy on the swimming performance of coho salmon (Oncorhynchus kisutch). Can J Fish Aquat Sci 46:243-245

Editorial responsibility: Tim Dempster,

Melbourne, Victoria, Australia
Smedley MA, Clokie BG, Migaud H, Campbell P and others (2016) Dietary phosphorous and protein supplementation enhances seawater growth and reduces severity of vertebral malformation in triploid Atlantic salmon (Salmo salar L.). Aquaculture 451:357-368

Solstorm F, Solstorm D, Oppedal F, Fernö A, Fraser TWK, Olsen RE (2015) Fast water currents reduce production performance of post-smolt Atlantic salmon Salmo salar. Aquacult Environ Interact 7:125-134

Stillwell EJ, Benfey TJ (1994) Hemoglobin level, metabolic rate, and swimming performance in triploid brook trout (Salvelinus fontinalis). In: MacKinlay DD (ed) High performance fish. Fish physiology. Elsevier, Amsterdam, p 288-293

Stillwell EJ, Benfey TJ (1996) Hemoglobin level, metabolic rate, opercular abduction rate and swimming efficiency in female triploid brook trout (Salvelinus fontinalis). Fish Physiol Biochem 15:377-383

Taranger GL, Carrillo M, Schulz RW, Fontaine P and others (2010) Control of puberty in farmed fish. Gen Comp Endocrinol 165:483-515

* Taylor JF, Sambraus F, Mota-Velasco J, Guy DR and others (2013) Ploidy and family effects on Atlantic salmon (Salmo salar) growth, deformity and harvest quality during a full commercial production cycle. Aquaculture 410-411:41-50

*Taylor JF, Waagbø R, Diez-Padrisa M, Campbell P and others (2015) Adult triploid Atlantic salmon (Salmo salar) have higher dietary histidine requirements to prevent cataract development in seawater. Aquacult Nutr 21: $18-32$

V Verhille C, Farrell AP (2012) The in vitro blood- $\mathrm{O}_{2}$ affinity of triploid rainbow trout Oncorhynchus mykiss at different temperatures and $\mathrm{CO}_{2}$ tensions. J Fish Biol 81:1124-1132

*Volonté MG, Yuln G, Quiroga P, Consolini AE (2004) Development of an HPLC method for determination of metabolic compounds in myocardial tissue. J Pharm Biomed Anal 35:647-653

Waagbø R, Bjerkås E, Sveier H, Breck O, Bjørnestad E, Maage A (1996) Nutritional status assessed in groups off smolting Atlantic salmon, Salmo salar L., developing cataracts. J Fish Dis 19:365-373

*Waagbø R, Tröße C, Koppe W, Fontanillas R, Breck O (2010) Dietary histidine supplementation prevents cataract development in adult Atlantic salmon, Salmo salar L., in seawater. Br J Nutr 104:1460-1470

*Wall AE (1998) Cataracts in farmed Atlantic salmon (Salmo salar) in Ireland, Norway and Scotland from 1995 to 1997. Vet Rec 142:626-631

*Wall AE, Richards RH (1992) Occurrence of cataracts in triploid Atlantic salmon (Salmo salar) on four farms in Scotland. Vet Rec 131:553-557

* Yamamoto A, Iida T (1994) Oxygen consumption and hypoxic tolerance of triploid rainbow trout. Fish Pathol 29:245-251

Submitted: July 5, 2017; Accepted: January 23, 2018

Proofs received from author(s): March 27, 2018 